\title{
Contemporary GIS needed skills to accommodate the changing geospatial technologies
}

Anwar-Elsadat Elmahal ${ }^{1}$

${ }^{1}$ Affiliation not available

February 25, 2022

\section{Hosted file}

Contemporary_GIS_needed_skills_to_accommodate_the_changing_geospatial_technologies.pdf available at https://authorea.com/users/156323/articles/557816-contemporary-gis-neededskills-to-accommodate-the-changing-geospatial-technologies 